\title{
Hubungan Konsep Diri dengan Perencanaan Karir Siswa di SMAN 1 Batipuh
}

\author{
Relia Yulianti', Alfi Rahmi², Rahmawati Wae ${ }^{3}$ \\ 1,2 Program Studi Bimbingan dan Konseling, Institut Agama Islam Negeri (IAIN) Bukittinggi \\ e-mail:
}

\begin{abstract}
ABSTRAK. Tujuan penelitian ini untuk mengetahui hubungan konsep diri dengan perencanaan karir siswa di SMA N 1 Batipuh. Jenis penelitian yang digunakan adalah pendekatan kuantitatif korelasional. Populasi dalam penelitian ini adalah siswa kelas XI IPA dan XI IPS di SMA N 1 Batipuh yang berjumlah 248 siswa. Teknik pengumpulan sampel yaitu Purposive Sampling dimana teknik penentuan sampel ini diambil secara acak tanpa memperhatikan strata yang ada pada populasi tersebut dengan jumlah sampel 62 siswa. Teknik pengumpulan data yaitu menggunakan skala likert dan teknik analisis data menggunakan uji normalitas, uji linearitas, uji hipotesis menggunakan korelasi product moment dengan bantuan Statistika Product and Service Solusion (SPSS) Versi 22. Hasil penelitian menunjukkan bahwa, data hasil uji normalitas model korelasi telah memenuhi asumsi normal yang berarti data dapat dikatakan berdistribusi normal. Berdasarkan hasil uji korelasi sederhana pada penelitian ini didapatkan bahwa $\mathrm{r}$ hitung $>$ dari $\mathrm{r}$ tabel $(0,926>0,246)$ dengan demikian dapat disimpulkan bahwa Ho ditolak dan Ha diterima terdapat hubungan yang signifikan antara konsep diri dengan perencanaan karir siswa kelas X1 IPA dan XI IPS di SMA N 1 Batipuh. Kemudian besarnya manfaat konsep diri dengan Perencanaan karir siswa di kelas XI IPA dan XI IPS sebesar 85,8\% dan 14,2\% di pengaruhi faktor lain.
\end{abstract}

Kata kunci: konsep diri, perencanaan karir, siswa

\section{Pendahuluan}

Salah satu tugas perkembangan yang harus dilalui oleh seorang remaja dalam masa perkembangannya di usia remaja adalah harus sudah dapat merencanakan karir bagi masa depannya. Hal ini menunjukkan perlu adanya strategi khusus untuk para remaja dalam mempersiapkan diri memasuki dunia kerja ketika sudah lulus dari bangku sekolah (Fatimah, 2008). Perlu adanya suatu bimbingan yang diberikan kepada siswa yang dapat membantu mereka dalam memahami kemampuan dirinya, serta dapat mengarahkan dirinya untuk dapat menyiapkan diri memasuki dunia kerja. Donald Super menyatakan bahwa konsep diri individu berperan penting dalam pemilihan karir seseorang (Sukardi, 1994).

Konsep diri menciptakan perasaan terarah dalam struktur kepribadian seseorang, dimana konsep diri seseorang dinyatakan melalui sikap dirinya. Manusia sebagai organisme yang memiliki dorongan untuk berkembang yang pada akhirnya menyebabkan kesadaran akan keberadaan dirinya, perkembangan yang berlangsung tersebut kemudian membantu pembentukan konsep diri individu (Nina, 2012). 
Konsep diri adalah keseluruhan gambaran diri, yang meliputi persepsi seseorang tentang diri, perasaan, keyakinan dan nilai yang berhubungan dengan dirinya. Individu yang memiliki motivasi yang positif dipandang mampu memiliki motivasi yang tinggi dalam menentukan karir yang akan dipilih secara tepat. Konsep diri meliputi apa yang kita pikirkan dan apa yang kita rasakan tentang diri kita sendiri, namun ketika terdapat individu yang memiliki konsep diri yang kurang baik maka ia merasa kurang yakin dengan apa yang akan diambilnya, tidak jelas dengan masa depannya dan mudah terpengaruh terhadap orang lain (Rakhmat, 2000).

Pada hakikatnya konsep diri merujuk bagaimana individu memahami dirinya sebagai pribadi jika dihadapkan dengan tugas- tugas perkembangannya, dalam kaitannya dengan tugas sesuai dengan tuntutan pribadi yang dihadapkan dengan tuntutan lingkungan dalam upaya optimalisasi individu. Individu akan berupaya mendefenisikan diri jika dihadapkan dengan upaya mengembangkan potensinya sesuai dengan apa yang dikerjakannya. Sehingga individu yang memiliki konsep diri yang positif berusaha dalam meraih kesuksesan akan lebih baik dibandingkan dengan orang yang memiliki konsep diri yang negatif. Dimana jika diri yang negatif cenderung berdampak negatif pula pada anak dalam menyelesaikan tugas dan tanggung jawabnya, diri memberikan sebuah kerangka berpikir yang menentukan bagaimana kita mengelola informasi tentang diri kita sendiri termasuk motivasi, keadaan emosional, evaluasi diri, kemampuan dan lain- lain (Surma, 2004).

Konsep diri merupakan pandangan atau penilaiaan remaja terhadap diri sendiri. Konsep diri yang tepat akan membantu remaja untuk mengenali dirinya dan merupakan alat kontrol bagi perilaku remaja. Konsep diri menjadi penting karena akan mempengaruhi remaja atau siswa dalam berinteraksi dengan lingkungan. Remaja yang memiliki konsep diri positif akan tampil lebih percaya diri dalam menghadapi berbagai situasi. Sebaliknya remaja yang mengembangkan konsep diri negatif, mempunyai kesulitan dalam menerima dirinya sendiri, sering menolak dirinya serta sulit bagi mereka untuk melakukan penyesuian diri yang baik. Dari sini ia kemudian mulai memandang dirinya dengan lebih realistik dan spesifik ini menandakan bahwa pada masa remaja individu mulai membentuk dan memiliki konsep diri yang lebih akurat (Respati., Yulianto., \& Widiana., 2006)

Konsep diri yang dimiliki oleh remaja akan mengalami perkembangan secara terusmenerus. Semakin luas pergaulan remaja dalam mengenal lingkungannya, maka semakin banyak pengalaman yang diperoleh remaja dalam kariernya. Kemampuan remaja terutama dalam menilai, memahami dirinya sendiri secara nyata sangat membantu untuk menentukan langkah selanjutnya yaitu memilih karir dengan tepat (Enung, 2008).

Karir merupakan suatu keseluruhan kehidupan seseorang dalam perwujudan diri untuk menjalani hidup dan mencapai tujuan. Untuk mencapai tujuan tersebut, individu harus memiliki kekuatan yang dimiliki seperti penguasaan kemampuan dan aspek yang menunjang kesuksesan karir. Perencanaan karir merupakan salah satu aspek paling penting dalam perkembangan karir individu. Kecakapan dalam mengambil keputusan mrupakan tujuan utama dalam perencanaan karir yang harus ditempuh oleh setiap individu (Atmaja, 2014).

Perlu disadari bahwa jika kita ingin memperoleh karir yang baik dan sesuai dengan harapan maka kita perlu membuat suatu perencanaan karir yang matang. Hurlock bahwa remaja yang lebih tua berusaha mendekati masalah karir dengan lebih praktis dan lebih realistis dibandingkan ketika ia masih anak- anak. Perencanaan karir adalah suatu proses dimana individu dapat 
mengidentifikasi dan mengambil langkah untuk mencapai suatu tujuan karirnya. Perencanaan karir adalah kemampuan seseorang untuk mengidentifikasi tujuan yang didalamnya melibatkan proses yang berkelanjutan berupaya perencanaan, pemahaman diri, penilaian kerja serta adanya pemahaman rasional terhadap suatu tujuan yang dapat menambah pengetahuan dan pemahaman diri sendiri (Walgito, 2011). Adapun langkah perencanaan karir yaitu menilai diri sendiri, menetapkan tujuan karir, membuat rencana dan melaksanakan rencana tersebut (Syahputra \& Hati, 2015).

Sebelum seseorang mengambil keputusan tentang karirnya maka dia memikirkan terlebih dahulu apa cocok karir ini dijalaninya atau tidak. Melalui perencanaan dalam karir setiap individu mengevaluasi kemampuan dan minat seseorang, mempertimbangkan kesempatan karir, alternatif, menyusun tujuan akhir dan merencanakan aktifitas pengembangan praktis. Dimana karir ini sangat penting bagi individu terutama untuk membangun sikap individu dalam menempuh karirnya ke depan. Seseorang akan bekerja senang hati dan penuh kegembiraan apabila apa yang dikerjakan itu memang sesuai dengan keadaan dirinya, kemampuan serta minat seseorang.

Berdasarkan teori yang telah dikemukan oleh Super bahwa pada usia 15-24 tahun telah terjadi proses kognitif dengan mengadakan berbagai eksplorasi sehingga berdasarkan kebutuhannya mereka memerlukan lebih banyak informasi untuk membuat keputusan meskipun belum keputusan final. Terjadinya proses ini mulai menentukan tujuan karir siswa melalui berbagai kesadran yang meungkin perlu diolah lebih jauh untuk mendapatkan keputusaan yang bijaksana dan perencanaan yang matang (Hidayati, 2014).

Berdasarkan fenomena yang sering terjadi dalam memilih karier dikalangan peserta didik (siswa) baik yang berhubungan dengan studi lanjut atau pekerjaan bahwa siswa SMA pada umumnya cenderung kurang mempertimbangkan beberapa hal dalam memilih studi lanjut atau pekerjaan, bahkan terkadang mengikuti teman- temannya dimana mereka berpikiran masih bisa bersama- sama lagi.

Berdasarkan wawancara yang dilakukan pada hari Senin tanggal 23 Mei 2019 dengan guru BK Ibu Yeni Efrita menunjukkan bahwa masih terdapat siswa yang bingung dalam memutuskan menentukan secara pasti arah cita- citanya kemana maupun karirnya walaupun beberapa siswa sudah menentukan pilihannya dan bahkan mengambil keputusan terhadap karir, sebagian siswa kurang memahami akan diri mereka sendiri dan bisa dikatakan siswa masih memiliki konsep diri yang negatif seperti merasa kemampuannya rendah dibanding dengan orang lain, apakah nantinya melanjutkan studi keperguruan tinggi atau bahkan terjun ke dunia kerja.

Hal ini juga didukung oleh hasil wawancara yang penulis lakukan pada tanggal 23 Mei 2019 dengan salah seorang siswa, dia mengatakan bahwa dia masih belum memikirkan rencana karir untuk ke depannya karena dia masih menikmati masa sekolahnya, misalnya mereka menikmati masa bermain dan kebersamaan dengan teman- temannya, masih ada yang bingung karena dia masih belum memahami dirinya sendiri terutama mengenai kemampuan yang menonjol dan cocoknya karir seperti apa nanti, ada yang belum punya pilihan setamat sekolah ini apa langsung melanjutkan studi ke perguruan tinggi atau bahkan bekerja, adapun siswa lainnya mengatakan bahwa mereka belum paham tentang perencanaan karir, kurang mendapatkan informasi, kurang pengetahuan/ wawasan dan mereka sendiri pun belum memahami lebih dalam terhadap kemampuan, bakat, minat yang dimiliki serta perencanaan karir seperti apa ke depannya nanti bahkan mereka sulit untuk mengambil keputusan, sebagian siswa merasa pesimis dalam 
merencanakan masa depan dengan baik, sebagian siswa belum mampu menetapkan rencana yang baik untuk mencapai tujuan dan harapan mereka dan sebagian siswa merasa tidak menyadari kelemahan dan keunggulan didalam dirinya terhadap perencanaan karir

Berdasarkan pemaparan tersebut penting bagi siswa untuk berusaha mengambil langkah yang tepat untuk memilih karir di masa depan dengan melihat gambaran diri seperti kelebihan dan kekurangan yang terdapat pada diri individu dan juga melihat peluang yang di sediakan dilingkungan.

\section{Metode}

Dalam Jenis penelitian ini adalah penelitian kolerasional dengan pendekatan kuantitatif. Lokasi penelitian yang akan dilakukan peneliti yaitu di SMA N 1 Batipuh, Kabupaten Tanah Datar. Adapun populasi dalam penelitian ini adalah siswa kelas XI IPS dan XI IPA. Adapun jumlah siswa kelas XI IPS dan XI IPS yaitu 248 orang. Untuk lebih jelasnya, banyak populasi dapat dilihat dari tabel di bawah ini:

Tabel 1. Populasi Penelitian

\begin{tabular}{ccc}
\hline No & Kelas & Banyak Siswa \\
\hline 1 & XI IPA 1 & 31 \\
2 & XI IPA2 & 31 \\
3 & XI IPA 3 & 31 \\
4 & XI IPS 1 & 31 \\
5 & XI IPS 2 & 31 \\
6 & XI IPS 3 & 31 \\
7 & XI IPS 4 & 31 \\
8 & XI IPS 5 & 31 \\
& Jumlah & $\mathbf{2 4 8}$ \\
\hline
\end{tabular}

Adapun populasi yang penulis pergunakan adalah apabila subjeknya kurang dari 100 orang, sebaiknya diambil seluruhnya saja sehingga penelitian ini merupakan penelitian populasi. Selanjutnya jika jumlahnya besar dari 100 orang diambil 10-15\% atau 20-25\% (Arikunto, 2012).

Berdasarkan pendapat tersebut, karena jumlah populasi penelitian lebih dari 100 orang yaitu 248 orang, maka diambil sampelnya yaitu 25\% sebanyak 8 orang. Adapun cara yang digunakan oleh peneliti dalam mengambil sampel yaitu purposive sampling (Sugiyono, 2016). Dalam menentukan jumlah sampel untuk setiap kelas peneliti melakukannya dengan cara:

\begin{tabular}{|c|c|c|}
\hline \multicolumn{3}{|c|}{ Tabel 2 Samnel Penelitian } \\
\hline No & Kelas & Banyak Siswa \\
\hline 1 & XI IPA 1 & 31 \\
\hline 2 & XI IPA2 & 31 \\
\hline 3 & XI IPA 3 & 31 \\
\hline 4 & XI IPS 1 & 31 \\
\hline 5 & XI IPS 2 & 31 \\
\hline 6 & XI IPS 3 & 31 \\
\hline 7 & XI IPS 4 & 31 \\
\hline 8 & XI IPS 5 & 31 \\
\hline & Jumlah & 248 \\
\hline
\end{tabular}




\section{Temuan}

Hasil skor data empirik variabel konsep diri pada bagian mean 89, 1452, pada bagian minimum 46. 00, maxsimum 127. 00, pada bagian std. deviasi 20, 50178, dan skor empirik variabel perencanaan karir pada bagian mean 86, 1290 , pada bagian minimum 54. 00, maxsimum 120. 00, pada bagian std. deviasi 18, 95680. Berdasarkan tabel konsep diri dapat diketahui bahwa 2 orang siswa dengan persentase $9,52 \%$ tersebut menyatakan bahwa konsep diri berada pada kategori sangat rendah, 12 orang siswa dengan persentase 57,14\% menyatakan bahwa konsep diri berada pada kategori rendah, 29 orang siswa dengan persentase 138, 09 berada pada kategori sedang, 22 orang siswa dengan persentase 104, 76 berada pada kategori tinggi dan 9 siswa dengan persentase 42, 85 berada pada kategori sangat tinggi.

Berdasarkan skor data empirik perencanaan karir dapat diketahui bahwa 1 orang siswa dengan persentase 4, 76\% tersebut menyatakan bahwa perencanaan karir berada pada kategori sangat rendah, 18 orang siswa dengan persentase $85,72 \%$ menyatakan bahwa perencanaan karir berada pada kategori rendah, 13 orang siswa dengan persentase 61, 90 berada pada kategori sedang, 18 orang siswa dengan persentase 85, 72 pada kategori tinggi dan 10 orang siswa dengan persentase 47, 62 berada pada kategori sangat tinggi. Berdasarkan hasil pengolahan yang dilakukan dengan SPSS versi 22 di dapatkan bahwa hasil uji korelasi terdapat hubungan antara variabel $\mathrm{X}$ dan $\mathrm{Y}$ adalah 0,926 . Untuk mengkorelasikan kedua variabel tersebut digunakan rumus degree of freedom $\mathrm{df}=\mathrm{n}-2(64-2=62)$. Berdasarkan pedoman interprestasi jika $\mathrm{r}$ hitung $>$ dari $\mathrm{r}$ tabel maka ada hubungan yang signifikan. Maka dapat diketahui bahwa terdapat korelasi (hubungan) yang signifikan antara konsep diri dengan perencanaan karir. Berdasarkan uji determinasi diketahui nilai R Square sebesar 0,858 Nilai R Square adalah sebesar kontribusi variabel X (konsep diri) terhadap variabel Y (perencanaan karir). Hal tersebut diketahui bahwa kontribusi konsep diri dengan perencanaan karir siswa sebesar 858\% dan 85.5\% dipengaruhi oleh faktor lain.

\section{Diskusi}

Sarwono (2009) berpendapat bahwa konsep diri mempengaruhi seseorang dalam mengangapai dunia dan pengalaman. Konsep diri juga berperan dalam pengambilan keputusan karir seseorang. Konsep diri dijadikan dasar bagi seseorang untuk memilih karir yang menurut kepribadiannya cocok. Individu perlu untuk mengatahui konsep dirinya sebelum mengambil keputusan karir karena dalam konsep diri terdapat persepsi seseorang mengenai bakat, minat dan kemampuannya. Selaras dengan teori Donald Super yang menyatakan bahwa konsep diri individu berperan penting dalam pemilihan karir seseorang (Santrock, 2007). Hal ini menunjukkan bahwa konsep diri berperan penting dalam pencapaian karir seseorang.

Konsep diri adalah salah satu pertimbangan yang jelas agar individu dapat menentukan arah karir masa depan dengan baik. Jika individu memahami konsep dirinya dengan baik, maka tugas perkembangan individu tersebut dapat tercapai dengan baik. Memahami diri sendiri sangatlah penting, karena pemahaman konsep diri yang benar individu dapat lebih mengetahui dirinya sendiri dan belajar untuk lebih menerima dirinya hingga dapat menentukan suatu pilihan dalam mengambil keputusan termasuk tentang karir dimasa depan.

Kemampuan peserta didik dalam menilai, memahami diri sendiri secara nyata akan membantu peserta didik untuk menentukan langkah selanjutnya yaitu memilih karir dengan tepat. 
Kemampuan perencanaan karir yang matang erat kaitannya dengan pemahaman peserta didik mengenai karir itu sendiri, suksesnya pencapaian karir seseorang dipengaruhi oleh adanya kemampuan perencanaan dan pengambilan keputusan yang matang

\section{Simpulan}

Berdasarkan hasil uji korelasi sederhana di peroleh $\mathrm{r}$ hitung sebesar 0, 926, sedangkan $\mathrm{r}$ tabel 0, 246, artinya 0,926>0,246 bahwa Ho ditolak dan Ha diterima artinya terdapat hubungan yang signifikan antara konsep diri dengan perencanaan karir siswa di SMA N 1 Batipuh. Besarnya manfaat konsep diri dengan perencanaan karir siswa kelas XI IPA dan XI IPS di SMA N 1 Batipuh sebesar $85.8 \%$ dan 14,2\% dipengaruhi oleh faktor lain.

\section{Referensi}

Alfaiz, A., \& Yandri, H. (2015). Self concept and self efficacy as a ground points in a social activities (an analysis of psychology perspective: a social cognitive theory). Jurnal Pelangi, 7(2).

Arikunto, S. (2012). Procedur Penelitian Suatu Pendekatan Praktek. Jakarta: Rineka Cipta.

Atmaja, T. T. (2014). Upaya meningkatkan perencanaan karir siswa melalui bimbingan karir dengan penggunaan media modul. Psikopedagogia, 3(2), 58-68.

Bagong, S., \& Sutinah. (2011). Metode Penelitian Sosial. Jakarta: Prestasi Pustakaraya.

Enung, F. (2008). Psikologi Perkembangan Peserta Didik. Bandung: Simbiosa Rekatama.

Jallaludin, R. (2000). Psikologi Konseling. Bandung: Remaja Rosdakarya.

Nina. (2012). Psikologi Sosial Sebagai Akar Ilmu Komunikasi. Bandung: Simbiosa Rekatama Media.

Rahmi, A., \& Yusri, F. (2017). Konsep Diri Mahasiswa Program Studi Bimbingan Konseling IAIN Bukittinggi. Islamic Counseling: Jurnal Bimbingan dan Konseling Islam, 1(2), 88-100.

Respati, W. S., Yulianto, A., \& Widiana, N. (2006). Perbedaan konsep diri antara remaja akhir yang mempersepsi pola asuh orang tua authoritarian, permissive, dan authoritative. Jurnal Psikologi, 4(2), 119-138.

Santrock, J. W. (2007). Remaja. Jakarta: PT Gelora Aksara Pratama.

Sarwono, S. (2009). Psikologi Sosial. Jakarta: Salemba Humanika.

Sugiyono. (2016). Metedologi Penelitian. Bandung: Alfabeta.

Sukardi, D. K. (1994). Penggunaan Tes dalam Konseling Karir. Surabaya: Usaha Offset Printing.

Syahputra, A., \& Hati, K. (2015). Pengembangan Sistem Career Center untuk Departemen Konseling dan Pengembangan Karir di Institut Teknologi Budi Utomo. Jurnal Khatulistiwa Informatika, 3(2).

Walgito, B. (2011). Bimbingan dan Konseling Karier di Sekolah. Jakarta: Prestasi Pustakarya.

Yandri, H., Juliawati, D., Alfaiz, A., Ramdani, R., Rusliah, N., Yuzarion, Y., ... \& Syaputra, Y. D. (2021). The Implementation of STIFIn Intelligence Test for Students' Career Planning: An Introduction and Impact of STIFIn Approach. Psychol Psychother Res Stud, 4(5). 